\title{
Effects of Treated Banana Peel Meal on the Feed Efficiency, Digestibility and Cost Effectiveness of Broiler Chickens Diet
}

\author{
Abel FAS $^{*}$, Adeyemi $\mathrm{OA}^{2}$, Oluwole $\mathrm{OB}^{1}$, Oladunmoye $\mathrm{OO}^{1}$, Ayo-Ajasa $\mathrm{OY}^{2}$ and Anuoluwatelemi JO \\ ${ }^{1}$ Federal Institute of Industrial Research, Oshodi (FIIRO), Food Tech Department, Animal House Section, Nigeria \\ ${ }^{2}$ Federal University of Agriculture, Abeokuta, Ogun State (FUNAAB), Animal Production and Health Department, \\ Nigeria
}

${ }^{*}$ Corresponding author: Abel FAS, Federal Institute of Industrial Research, Oshodi (FIIRO), Food Tech Department, Animal House Section, Nigeria, Tel: 234-802-3295-970, E-mail: silasabel@ymail.com, silas. abel@fiiro.gov.ng

Citation: Abel FAS, Adeyemi OA, Oluwole OB, Oladunmoye OO, Ayo-Ajasa OY, et al. (2015) Effects of Treated Banana Peel Meal on the Feed Efficiency, Digestibility and Cost Effectiveness of Broiler Chickens Diet. J Vet Sci Anim Husb 3(1): 101. doi: 10.15744/2348-9790.1.603

Received Date: February 02, 2015 Accepted Date: February 24, 2015 Published Date: February 27, 2015

\begin{abstract}
The study was conducted to investigate effect and the nutritive value of treated banana peel meal at substitutionary levels for maize and other ingredients on the feed efficiency, digestibility and cost effectiveness on broiler chickens diet. A total of one hundred and eighty (180) Arbor Acres broilers were randomly distributed into four treatment groups of 0\%-control, 10, 20 and 30\% inclusion of treated banana peel meal as $\mathrm{T}_{0}, \mathrm{~T}_{10}, \mathrm{~T}_{20}$ and $\mathrm{T}_{30}$ treatments respectively. Each treatment had 45 broiler birds with three replicates of 15 birds per replicate and the experiment lasted 4 weeks. The rations were made isonitrogenous and isocaloric. The birds were randomly distributed in a completely randomized design and Duncan multiple range test was used to separate means having significant differences ( $\mathrm{p}<$ 0.05). The results showed that the final liveweight was significantly highest at $\mathrm{T}_{0}\left(1997.80 \mathrm{~g}\right.$ ) compared to $1896.22 \mathrm{~g}$ and $1841.83 \mathrm{~g}$ in $\mathrm{T}_{20}$ and $\mathrm{T}_{30}$ respectively. The daily weight gain was lowest $(\mathrm{p}<0.05)$ in $\mathrm{T}_{30}$ with a value of $44.87 \mathrm{~g}$ compared to $\mathrm{T}_{0}$ and $\mathrm{T}_{10}$ which were same statistically though numerically different. The feed efficiency ratio decreased as the level of peel meal inclusion increased from $\mathrm{T}_{0}, \mathrm{~T}_{10}$, $\mathrm{T}_{20}$ to $\mathrm{T}_{30}(0.36,0.34,0.32$ and 0.29$)$. The dry matter and crude protein digestibility were significantly highest $(87.21 \%$ and $87.52 \%)$ at

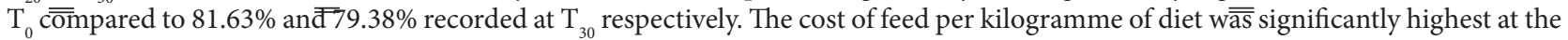
$\mathrm{T}_{0}$ (N105.54) compared to $\mathrm{N} 97.50$ in $\mathrm{T}_{30}$ treatment. The feed cost savings was significantly highest at $\mathrm{T}_{30}(\mathrm{~N} 9.32)$ with the lowest value of $\mathrm{N} 4.85$ recorded in $\mathrm{T}_{10}$. It was concluded that banana peel meal can be added up to $10 \%$ in broiler chicken diet without any adverse effect on the performance of the birds thus enriching the poultry productions business.
\end{abstract}

Keywords: Isonitrogenous; Alternative feedstuffs; Pericarp; Digestibility; Isocaloric

\section{Introduction}

Banana (Musa sapientum) is a monocotyledonous plant that originated from the South-East Asian countries with two main species, Musa acuminata and Musa balbisiana from Malaysia and India respectively [1-3]. There were different banana types, genomes and hybrids which had been widely cultivated [4,5]. Banana, widely cultivated in Africa is very rich in potassium and calcium but low in sodium content $[1,6,7]$. It had a medicinal use in people with high blood pressure and stroke $[8,9]$, and also reported to help to stimulate the production of hemoglobin and also have hypolipidemic effects [10,11]. The pulp of banana is used for food or feed however; less work had been done on the nutritive value of banana peel meal as alternative feedstuffs in poultry production [10,12]. In poultry production business, feeding is the most expensive singular input, it accounts for between $65-70 \%$ of the total cost of production [13-15]. Banana peel is an alternative feedstuff for animal feeding which can be sourced from local banana market stands and banana processing industry $[11,16]$. Banana is rich in potassium and low in sodium thus highly recommended for people with high blood pressure [3,17]. Banana pericarp (peel) had been treated for poultry use in order to remove or lower the anti-nutritional factors, this includes using different treatment techniques like addition of ash and covering for 3-5 days, sun drying for 4-5 days, oven dried for $2 \mathrm{hrs}$ at $100^{\circ} \mathrm{C}$ and use of different alkali and sodium hydroxide amongst others [2,18]. The inclusion of waste banana fruit in the ration of swine had been reported $[19,20]$ while other authors had reported the use of banana peel meal in broiler chickens $[5,11,16,18,21]$. The banana pericarp contains some anti-nutritional factors like tannins, oxalate and phytate amongst others which could induce adverse effects like depressive growth, reduced feed efficiency and vital organs damage in the body which may ultimately lead to mortality in birds and great losses in poultry enterprise if good processing techniques to detoxify these anti-nutritional factors are not carried out [22,23]. Banana peel contains higher crude fibre, ash and low crude protein compared to the mesocarp (pulp) and this makes it a good alternative feedstuff for animal feeding [24,25]. Therefore, the aim of this research is to evaluate the nutritive value of treated banana peel meal (TBPM) in broiler chickens diet. 


\section{Materials and Methods}

\section{Banana Collection, Processing and Storage}

Ripened banana peels were collected at the popular local banana stand of Oshodi main market. The banana peels were sorted and washed with clean water to remove the dirt and stones. They were later spread openly on jute bags over cemented floor under high sun intensity for 4-5 days. When a high dehydration had been achieved, they were transferred to the cabinet tray drier and dried at $125^{\circ} \mathrm{C}$ for 25 minutes. Cooling and air-drying was done to obtain a well dried crispy banana peel which was packaged for onward milling using Apex ${ }^{\circledast}$ Hammer Mill. The banana peel meal was later subjected to proximate analysis for the study. Chemical analysis was done [26-28] and the determined moisture content was $<10 \%$ to enable a good and longtime storage. The crude protein and crude fibre analysis results for the banana peel meal was 1.93 and $26.68 \%$ respectively.

\section{Housing and Treatment}

The study was carried out in the deep litter section of the Epe Poultry Farms in Lekki Area of Lagos State, Nigeria for a period of 4 weeks ( $5^{\text {th }}$ to $8^{\text {th }}$ week of bird's age). The housing was well ventilated with a concrete flooring system and wire nettings on either side for proper ventilation. The pen was open sided for easy and proper ventilation while the wood shaving was used as litter material. The housing was fumigated with Enlol ${ }^{\circledR}$ E.C, $5 \mathrm{mls}$ per 100 liters of water, two weeks before the arrival of the birds and locked up for two days. It was opened and washed with clean water, four days prior to stocking with birds and ventilated. The feeders and drinkers were washed and clean water for drinking was provided ad libitum. The birds were randomly distributed and used for the study.

\section{Birds, Diet and Health}

One hundred and eighty day old Arbor Acres broiler chicks were used for the study. The birds were assigned to four dietary treatments following a completely randomized design (CRD). The four test diets designated as $\mathrm{T}_{0}, \mathrm{~T}_{10}, \mathrm{~T}_{20}$ and $\mathrm{T}_{30}$ were formulated to contain $0,10,20$ and $30 \%$ of treated banana peel meal (TBPM) to replace maize and other ingredients. The feed compounded were made isonitrogenous and isocaloric (Table 1). Proper medication and vaccination programs were strictly carried out and good bio-security measure was maintained.

The broiler chicks collected at day old were weighed on arrival at the farm and weekly thereafter. The chicks were brooded for two weeks and fed for another two weeks making the four weeks of the starter phase. Data collection started from the fifth week to the eight week of the study (finisher phase). The experimental birds were weighed at the end of the starter phase and this marked the initial weight of the birds for the commencement of the study and data collection at the finisher phase. The birds were then randomly allotted according to the bodyweight uniformity for the different treatments which were replicated thrice. Birds were given 24 hours of free access to clean water (ad libitum) daily while lighting regimen of $22 \mathrm{hrs}$ of light and 2 hrs of dark was maintained.

The diets were formulated to meet the requirement of the broiler chickens according to the National Research Council [29].

\section{Data Collection and Analysis}

The data collected were on feed efficiency, digestibility and cost evaluation at the finisher phase of growth from the $5^{\text {th }}$ to the $8^{\text {th }}$ weeks of age.

\section{Feed Efficiency (Growth performance)}

The feed efficiency (growth performance) was monitored daily and weekly thereafter. The feed intake was measured by subtracting the feed remaining from that supplied the previous day. The birds were also weighed daily for one week at the starter phase and weekly (for four weeks) thereafter using Camry ${ }^{\oplus}$ electronic digital scale $0.01 \mathrm{~g}$. Initial weight was subtracted from the final weight to get the weight gain. The feed efficiency ratio (FER) was obtained by dividing the average weight gain (g) by the feed intake (g) for the growth performance analysis. Mortality was also monitored for any death in the flock within the data collection period. No bird was culled.

\section{Digestibility Analysis}

This was done using the total collection method where three birds per treatment were selected and put into the digestibility cage having a flat aluminum tray for easy collection of excreta materials. The birds were acclimatized to the digestibility cage for three days followed by four days total collection of excreta samples. Feather and feed were prevented from falling inside the collecting tray of the excreta materials. Collection of the excreta was done twice daily, they were weighed and stored at $4{ }^{\circ} \mathrm{C}$ in a refrigerator and it was later pooled and analyzed. The proximate compositions of the feed and collected excreta droppings was estimated to determine content of the dry matter, crude protein, crude fiber, ether extract, ash and nitrogen-free extract [26].

\section{Feed Cost Analysis}

The feed cost $($ ) was calculated by adding the sum of the total feed ingredients costs used in the composition of the diet. The cost of feed per kg weight gain was computed by the multiplication of the cost with the feed conversion ratio. The feed cost savings was calculated as initial (control) cost minus final cost divided by initial cost multiplied by hundred. 
Feed cost savings $=$ Initial cost - Final Cost X 100

Initial Cost

The cost of daily feed intake per bird ( $)$ was arrived at by multiplying the cost of feed/kg by the quantity (g) of feed taken daily Cost of daily feed intake per bird = Cost of feed/kg X Quantity of daily feed intake

\begin{tabular}{|c|c|c|c|c|}
\hline Ingredients & $\mathrm{T}_{0}$ & $T_{10}$ & $T_{20}$ & $\mathbf{T}_{30}$ \\
\hline Maize & 564.00 & 507.60 & 451.20 & 394.80 \\
\hline Soybean Meal & 159.00 & 160.00 & 168.00 & 171.00 \\
\hline Groundnut cake & 120.00 & 124.00 & 119.00 & 116.00 \\
\hline Brewers Dry Grain & 15.00 & 15.00 & 10.00 & 20.00 \\
\hline Wheal Offal & 70.00 & 65.00 & 60.00 & 44.00 \\
\hline $\begin{array}{l}\text { Treated Banana Peel } \\
\text { Meal (TBPM) }\end{array}$ & 0.00 & 56.40 & 112.80 & 169.20 \\
\hline Palm oil & 5.00 & 5.00 & 12.00 & 18.00 \\
\hline Fish Meal & 25.00 & 25.00 & 25.00 & 25.00 \\
\hline Bone Meal & 28.00 & 28.00 & 28.00 & 28.00 \\
\hline Oyster Shell & 7.00 & 7.00 & 7.00 & 7.00 \\
\hline Lysine & 2.00 & 2.00 & 2.00 & 2.00 \\
\hline Methionine & 1.00 & 1.00 & 1.00 & 1.00 \\
\hline Premix & 2.00 & 2.00 & 2.00 & 2.00 \\
\hline Salt & 2.00 & 2.00 & 2.00 & 2.00 \\
\hline TOTAL & 1000 & 1000 & 1000 & 1000 \\
\hline \multicolumn{5}{|l|}{ Determined Analysis\% } \\
\hline Dry Matter (DM) & 91.45 & 91.25 & 90.62 & 89.58 \\
\hline $\mathrm{CP}$ & 19.34 & 19.21 & 19.25 & 19.16 \\
\hline $\mathrm{CF}$ & 4.34 & 4.69 & 5.74 & 6.20 \\
\hline Ether Extract & 4.69 & 4.97 & 5.31 & 5.28 \\
\hline Ash & 5.63 & 5.81 & 6.49 & 6.89 \\
\hline NFE & 57.45 & 56.57 & 53.83 & 52.08 \\
\hline \multicolumn{5}{|l|}{ Calculated Analysis } \\
\hline ME: Protein ratio & 153.42 & 152.30 & 151.26 & 150.45 \\
\hline Calcium & 1.11 & 1.13 & 1.15 & 1.16 \\
\hline Phosphorus & 0.53 & 0.52 & 0.53 & 0.53 \\
\hline Methionine & 0.41 & 0.45 & 0.45 & 0.39 \\
\hline Lysine & 1.17 & 1.21 & 1.16 & 1.15 \\
\hline $\mathrm{MJ} / \mathrm{KG}$ & 12.42 & 12.25 & 12.19 & 12.07 \\
\hline
\end{tabular}

*provided $\mathrm{g} \mathrm{kg}^{-1}$ of diet- Vitamin A (12,000IU); Vitamin $\mathrm{D}_{3}$ (2.500IU); Vitamin E (30,000IU);Vitamin $\mathrm{K}_{3}$ $(2,000 \mathrm{mg})$; Vitamin B2-Riboflavin (3mg); Vitamin B3-Nicotinic acid (10mg):VitaminB5(15mcg)-Pantothen cacid(15,000mg);Manganese(80,000mg);Zinc(50mg); Copper(5mg); Iodine(1,000mg); Cobalt (Co) $(0.2 \mathrm{mg})$; Selenium (Se) (0.1mg)), Folic acid (1,500mg),Biotin (50 mcg); Choline chloride (300,000mg)

Table 1: Composition of experimental diets $\left(\mathrm{g} \mathrm{kg}^{-1}\right)$

\section{Statistical Analysis}

The data collected were subjected to a one way analysis of variance (ANOVA) in a completely randomized design arrangement. The means that were significantly different were compared using the Duncan's Multiple Range Test (DMRT) procedure [30]. 


\section{Results and Discussion}

The results obtained for the processed treated banana peel meal (TBPM) analysis showed that the crude protein (1.93\%) was a higher than $0.09 \%$ reported by Duwa et al [19] while the crude fiber value of $26.68 \%$ was lower than $31.70 \%$ reported by the same author. This could be due to the quality of banana peel processed and the different processing and analytical techniques used.

The results of the growth performance (Table 2) showed that the final live weight decreased significantly $(\mathrm{p}<0.05)$ as the level of inclusion of the TBPM increased. The final live weight value of $1997.80 \mathrm{~g}$ in $\mathrm{T}_{0}$ was significantly highest $(\mathrm{p}<0.05)$ compared to $1933.17 \mathrm{~g}, 1896.22 \mathrm{~g}$ and $1841.83 \mathrm{~g}$ in $\mathrm{T}_{10}, \mathrm{~T}_{20}$ and $\mathrm{T}_{30}$ respectively. The decreasing weight gain trend which had also been reported [18] could be due to the effect of the increasing levels of the banana peel meal inclusion in the diet and the poorer feed efficiency ratio (FER) observed especially in $\mathrm{T}_{30}$ with 0.29 FER compared to 0.36 in $\mathrm{T}_{0}$ treatment. The daily feed intake increased ( $\mathrm{p}<0.05$ ) as the level of inclusion of TBPM increased; it was highest $(\mathrm{p}<0.05)$ in $\mathrm{T}_{30}$ with a value of $149.71 \mathrm{~g}$ compared to $141.32,140.63$ and $146.44 \mathrm{~g}$ in $\mathrm{T}_{0}, \mathrm{~T}_{10}$ and $\mathrm{T}_{20}$ respectively. Birds eat to satisfy the energy requirements and this could be responsible for the high feed intake in $\mathrm{T}_{20}$ and $\mathrm{T}_{30}$ in contrast to others $[5,31]$.

The mortality was significantly highest $(\mathrm{p}<0.05)$ in the $\mathrm{T}_{20}$ with a value of $3.25 \%$ while the lowest value of $1.32 \%$ was recorded in $\mathrm{T}_{10}$. The post mortem examination after the veterinary examination and diagnosis showed feed impaction in the tracheal region which could suggest tracheal blockade as a result of higher feed impaction during feed ingestion. A mild bacterial infection was diagnosed especially in the fifth week where the few birds showing signs like sleeping and staying away from the feeders were culled and treated symptomatically and since there was no death, after four days they were returned to their pen.

The cost evaluation analysis (Table 3) showed that the cost of feed/ $\mathrm{kg}$ of diet was highest $(\mathrm{p}<0.05)$ in $\mathrm{T}_{1}$ with a value of 105.54 while $\mathrm{T}_{2}, \mathrm{~T}_{3}$ and $\mathrm{T} 4 \mathrm{had} \$ 100.42$, $\$ 98.59$ and $\$ 95.70$ respectively. The lowered costs in $\mathrm{T}_{2}-\mathrm{T}_{4}$ is as a result of cheap (free) sourcing of the alternative feedstuff (TBPM), as it replaced that of maize in the respective diet. Abel et al $[13,14]$ had also reported that there is lowered feed cost when an alternative feed ingredient is used in place of the conventional feedstuffs. The cost of daily feed intake per bird was highest $(\mathrm{p}<0.05)$ in the $\mathrm{T}_{1}(\mathrm{14.49})$ as against $(\mathrm{14.32})$ in $\mathrm{T}_{4}$. The cost of feed/kg weight gain was significantly ( $\mathrm{p}>$ 0.05 ) highest in $T_{4}$ with a value of $\$ 317.71$ while the lowest cost of $\$ 293.40$ and $\$ 292.22$ was recorded in $T_{1}$ and $T_{2}$ respectively. This was due to the lower weight gain recorded in $\mathrm{T}_{4}$ and a bad feed conversion ratio value.

The feed savings cost analysis showed that $\mathrm{T}_{4}$ had the highest $(\mathrm{p}<0.05)$ cost savings of $¥ 9.32$ compared to $¥ 4.85$, $¥ 6.59$ in the $\mathrm{T}_{2}$ and $\mathrm{T}_{3}$ treatments respectively, this increment in feed savings cost is attributable to the low cost of the treated banana peel meal at the point of sourcing as an alternative feed source compared to the conventional maize in the control.

\begin{tabular}{|c|c|c|c|c|c|}
\hline Parameters & $\mathrm{T}_{\mathbf{0}}$ & $\mathrm{T}_{10}$ & $\mathrm{~T}_{20}$ & $\mathrm{~T}_{30}$ & SEM \\
\hline Initial liveweight (g/bird) & 579.43 & 578.65 & 586.43 & 585.59 & 2.11 \\
\hline Final liveweight (g/bird) & $1997.80^{\mathrm{a}}$ & $1933.17^{\mathrm{ab}}$ & $1896.22^{\mathrm{b}}$ & $1841.83^{\mathrm{c}}$ & 11.52 \\
\hline Daily weight gain (g/bird) & $50.66^{\mathrm{a}}$ & $48.38^{\mathrm{a}}$ & $46.79^{\mathrm{b}}$ & $44.87^{\mathrm{c}}$ & 0.74 \\
\hline Daily feed intake (g/bird) & $141.32^{\mathrm{b}}$ & $140.63^{\mathrm{b}}$ & $146.44^{\mathrm{a}}$ & $149.71^{\mathrm{a}}$ & 1.75 \\
\hline Feed Efficiency Ratio (FER) & $0.36^{\mathrm{a}}$ & $0.34^{\mathrm{b}}$ & $0.32^{\mathrm{b}}$ & $0.29^{\mathrm{c}}$ & 0.08 \\
\hline Daily protein intake (g/bird) & 27.33 & 27.02 & 26.65 & 26.23 & 1.24 \\
\hline Protein efficiency ratio (PER) & $1.85^{\mathrm{a}}$ & $1.79^{\mathrm{a}}$ & $1.76^{\mathrm{b}}$ & $1.71^{\mathrm{c}}$ & 0.07 \\
\hline Mortality (\%) & $1.47^{\mathrm{b}}$ & $1.32^{\mathrm{b}}$ & $3.25^{\mathrm{a}}$ & $1.43^{\mathrm{b}}$ & 0.09 \\
\hline
\end{tabular}

${ }^{\text {abc }}$ Means within same row with different superscripts differ significantly $(\mathrm{P}<0.05)$ SEM- Standard Error of Means; TBPM-Treated Banana Peel Meal

Table 2: Effect of TBPM on the growth performance of broiler diet

\begin{tabular}{|c|c|c|c|c|c|}
\hline Parameters & $\mathbf{T}_{\mathbf{0}}$ & $\mathbf{T}_{\mathbf{1 0}}$ & $\mathbf{T}_{\mathbf{2 0}}$ & $\mathbf{T}_{\mathbf{3 0}}$ & SEM \\
\hline Cost of feed/kg of diet ( & $105.54^{\mathrm{a}}$ & $100.42^{\mathrm{b}}$ & $98.59^{\mathrm{ab}}$ & $95.70^{\mathrm{b}}$ & 7.26 \\
\hline Cost of daily feed intake/bird ( $)$ & $14.49^{\mathrm{a}}$ & $14.12^{\mathrm{c}}$ & $14.44^{\mathrm{a}}$ & $14.32^{\mathrm{b}}$ & 4.31 \\
\hline Cost of feed/kg weight gain ( $)$ & $293.40^{\mathrm{b}}$ & $292.22^{\mathrm{b}}$ & $307.61^{\mathrm{a}}$ & $317.71^{\mathrm{a}}$ & 11.06 \\
\hline Feed cost savings (\%) & - & $4.85^{\mathrm{b}}$ & $6.59^{\mathrm{b}}$ & $9.32^{\mathrm{a}}$ & 0.09 \\
\hline
\end{tabular}

${ }_{\text {abc }}$ Means within same row with different superscripts differ significantly $(\mathrm{P}<0.05)$ SEM- Standard Error of Means; TBPM-Treated Banana Peel Meal

Table 3: Effect of TBPM on the cost evaluation and economic analysis of broiler diet

The effects of the treated banana peel meal on the digestibility co-efficients of the broiler diet are presented in Table 4 . The dry matter digestibility was significantly highest in $\mathrm{T}_{0}$ with a value of $87.21 \%$ compared to the lowest value of $81.63 \%$ in $\mathrm{T}_{30}$. The crude protein digestibility was significantly highest in $\mathrm{T}_{0}(87.52 \%)$ and lowest value of $79.38 \%$ in $\mathrm{T}_{30}$, this could be attributed to the increasing levels of the treated banana peel meal in the respective diets $[7,9,18]$. The $\mathrm{T}_{10}$ and $\mathrm{T}_{20}$ treatments recorded $86.49 \%$ and $81.81 \%$ respectively. The lowering value in the parameters could be due to the inability of the birds to digest the nutrients therein in the feed and also, increasing inclusions of the treated banana peel meal $[5,16,17,23]$. The ether extract digestibility was highest $(\mathrm{p}<0.05)$ in the $\mathrm{T}_{10}$ with $93.39 \%$ compared to $90.78 \%$ in $\mathrm{T}_{20}$ treatment. 


\begin{tabular}{|c|c|c|c|c|c|}
\hline Parameters & $\mathbf{T}_{\mathbf{0}}$ & $\mathbf{T}_{\mathbf{1 0}}$ & $\mathbf{T}_{\mathbf{2 0}}$ & $\mathbf{T}_{\mathbf{3 0}}$ & $\mathbf{S E M}$ \\
\hline Dry matter Digestibility & $87.21^{\mathrm{a}}$ & $86.45^{\mathrm{a}}$ & $84.84^{\mathrm{a}}$ & $81.63^{\mathrm{b}}$ & 1.18 \\
\hline Crude Protein Digestibility & $87.52^{\mathrm{a}}$ & $86.49^{\mathrm{a}}$ & $81.81^{\mathrm{a}}$ & $79.38^{\mathrm{b}}$ & 2.04 \\
\hline Crude Fibre Digestibility & 76.36 & 73.54 & 74.43 & 71.09 & 2.38 \\
\hline Ether Extract Digestibility & 91.43 & 93.39 & 90.78 & 92.01 & 3.17 \\
\hline
\end{tabular}

abc Means within same row with different superscripts differ significantly $(\mathrm{P}<0.05)$ SEM- Standard Error of Means; TBPM-Treated Banana Peel Meal

Table 4: Effect of TBPM on the digestibility co-efficient of broiler diet

\section{Conclusion}

It is hereby concluded that the treated banana peel meal can be included in the broiler finisher feed up to $10 \%$ inclusion without any adverse effect on the growth performance of the broiler birds. It also positively leads to cost reduction in feed purchase thus a lowered cost of production and a better feed conversion ratio.

\section{Acknowledgement}

We want to thank the team members for the success of this research work. Mr. Emmanuel of Epe Poultry Farms, Epe, Lagos State is highly appreciated for his unquantifiable technical supports.

\section{References}

1. Archibald JG (1949) Nutrient composition of banana skins. J Dairy Sci 32: 969-71.

2. Ngeze PB (1994) Bananas and their management ( $1^{\text {st }}$ edn) Kagera Writers and Publishers Cooperative Society Limited, Bukoba, Tanzania.

3. Sharrock S (1996) Uses of Musa INIBAP annual report 1996.

4. Pamplona-Roger GD (2002) Healthy Foods A collection of new lifestyles, Editorial Safeliz S L Publishers, Spanish.

5. Widjastuti T, Hernawan E (2012) Utilizing of Banana Peel (Musa Sapientum) in the ration and its influence on final body weight, percentage of carcass and abdominal fat on broilers under heat stress condition. Lucrari Stiintifice-Seria Zootehnie 57: 104-9.

6. AdisaVA, Okey EN (1987) Carbohydrate and protein composition of banana pulp and peel as influenced by ripening and mold contamination. Food Chemistry 25: 85-91.

7. Anhwange BA (2008) Chemical composition of Musa sapientum (banana) peels. J Food Tech 6: 263-6.

8. Gowen S (1995) The nutritional value of bananas In Bananas and Plantains Chapman \& Hall Publishers, UK.

9. Dacie JV, Lewis SN (1991) Practical haematology ( $8^{\text {th }}$ edn) Longman group, Churchill Livingstone Publisher, London.

10. Qotimah S (2012) Utilization of Waste Banana Skin For Poultry Feed.

11. World Health Organization (1980) Manual of Basic Techniques for a Health Laboratory. World Health Organization, Geneva, Switzerland.

12. Bamgbose AM, Jegede AV, Idowu OMO, Oso OA, Abioye AO (2006) Utilization of fermented pigeon pea (Cajanus cajan) by broiler chickens. Book of proceedings, 2nd International Poultry Summit World Poultry Science Association Nigerian Branch (WPSA - NB). Gateway Hotel, Ogun State, Nigeria. 83-9.

13. Abel FAS, Eruvbetine D, Sogunle OM, Owolabi FO, Elemo GN, et al. (2014) Response of finishing broiler chickens to different stocking densities and quantitative feeding regimens. Int J Appli Res Tech 3: 83-8.

14. Silas AFA, Ayorinde AO, Daisy E, Mark SO, Bolanle OO, et al. (2014) Effect of stocking density and quantitative feed restriction on growth performance, digestibility, haematological characteristics and cost of starting broiler chicks. J Anim Health Prod 2: 60-4.

15. Maina HM, Heidi ES, Shagal MH (2012) Analytical screening of nutritional and non-essential components in unripe and ripe fruits of banana (Musa sapientum). Int J Medicinal Plant Res 1: 20-5.

16. Tewe OO (1983) Replacing maize with plantain peels in the diet of broiler. Nutrition Reports International 28: 23-8.

17. Gomez M (1982) Nutritional characteristics of some selected Non-conventional feedstuff: their acceptability, improving and Potential use in poultry feeds. Proceedings of a workshop on applied research, Nairobi, Kenya.

18. Atapattu NSBM, Senevirathne TSMS (2012) Effects of increasing levels of dietary cooked and uncooked banana meal on growth performance and carcass parameters of broiler chicken. Pak Vet J 33: 179-82.

19. Duwa H, Saleh B, Lamido M, Saidu A (2014) Growth, haematological and serum biochemical indices of broiler chickens fed banana peel meal as replacement for maize in the semi-arid zone of Nigeria. J Anim Feed Res 4: 121-6.

20. Forster M, Redriguez ER, Martin JD, Romero CD (2003) Distribution of nutrients in edible banana pulp. Food Technology Biotechnology 41: 167-8.

21. Gohl B (1981) Musa Paradisiaca L. Banana plantain or cooking banana. Tropical feeds. Feed information summaries and nutritive values. FAO, Rome.

22. Bowrey I, Buckle RG, Hamey KA, Pavenayotin P (1980) Use of solar energy for banana drying. Food Technology in Australia 32: $290-1$.

23. Ly J (1990) The physiological and biochemical basis for feeding pigs and poultry in the tropics (part 1). Livestock Res Rural Develop 2: 3-5.

24. Okujagu TF (2005) Medicinal Plants of Nigeria: South-South Zone Vol 1. Nigeria Natural Medicine Development Agency, CSS Bookshops Limited publishers, Nigeria.

25. Oluyemi J, Roberts FA (2000) Poultry production in warm wet climates ( $2^{\text {nd }}$ edn) Spectrum Books Limited, Ibadan, Nigeria.

26. AOAC (2000) Official methods of analysis Association of Official Analytical Chemists (18 ${ }^{\text {th }}$ edn), Washington DC, USA.

27. Nielsen SS (1994) Introduction to chemical analysis of foods, Chapman \& Hall Publisher, Boston, London. 
28. Omenka RO, Anyasor EN (2010) Vegetable-Based Feed Formulation on Poultry Meat Quality. Afri J Food Agri Nutri Develop 10: 5-7.

29. NRC (1994) National Research Council-Nutrient Requirement in Poultry ( $9^{\text {th }}$ edn) National Academy Press. Washington DC, USA.

30. Steel RGD, Torrie JH (1990) Statiscal Analysis System User' guide. Statistical SAS.

31. Saroeun K, Ogle B, Preston TR, Borin K (2010) Feed selection and growth performance of local chickens offered different carbohydrate sources in fresh and dried form supplemented with protein-rich forages. Livestock Res Rural Develop 22.

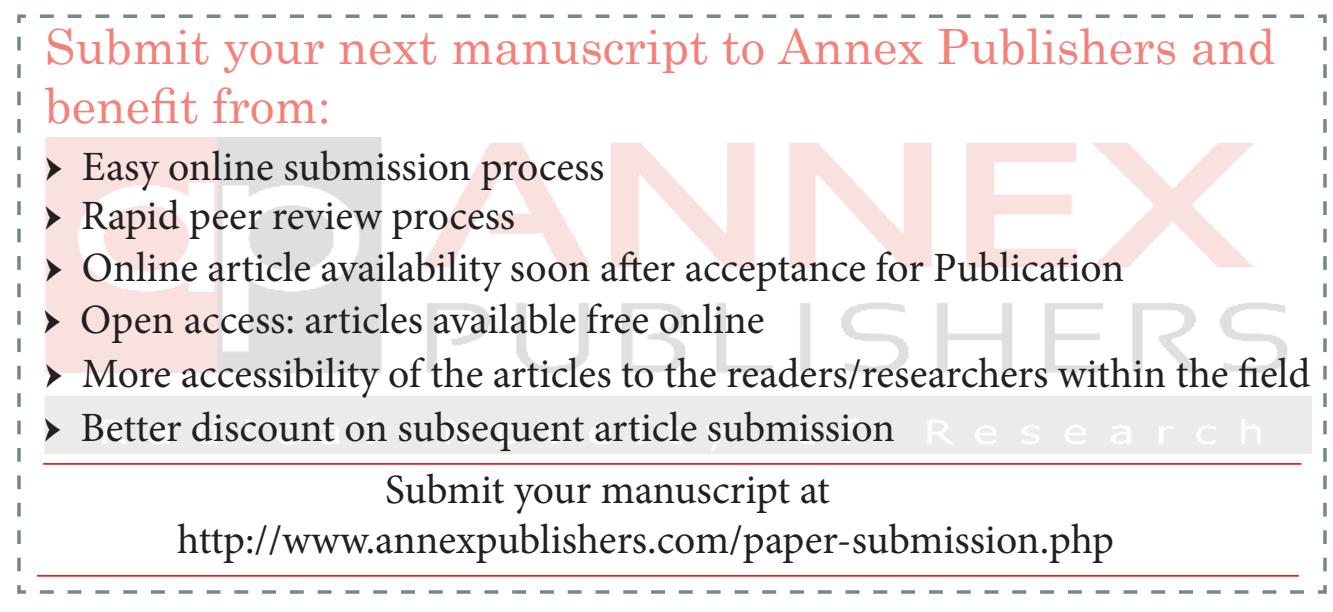

